\title{
RESEARCH OF ACUTE TOXICITY AND ANTI-INFLAMMATORY ACTIVITY OF EXTRACTS OF ERYNGIUM PLANUM
}

Andrii Grytsyk ${ }^{1}$ (Doctor of Pharmaceutical Sciences, Professor), Kseniia Gnatoyko ${ }^{1}$ (PhD in Pharmaceutical Sciences, Associate Professor)

1 Ivano-Frankivsk National Medical University, IvanoFrankivsk, Ukraine

*Corresponding author: Kseniia Gnatoyko
Received: December 29, 2021

Published: January 23, 2022

\begin{abstract}
Most pathological processes in the human body of various origins are accompanied by signs of inflammation, namely: swelling (tumor), redness (rubor), fever (calor), pain (dolor) and dysfunction of a particular organ or system (functio laesa). The pathological process of inflammation is a response to the action of external or internal phlogogenic agents. Today, nonsteroidal anti-inflammatory drugs are the main drugs for the treatment of inflammatory processes. Therefore, one
\end{abstract}

of the key tasks of pharmacy is the development and research of herbal anti-inflammatory drugs. One of the promising plants that has antiinflammatory action is Eryngium planum. These are plants that belong to the family Apiaceae (Umbelliferae) and contain a large number of biologically active substances.

Keywords: eryngium, apiaceae, medicinal plants, anti-inflammatory action.

Introduction. Today, first-line drugs in the treatment of inflammatory processes are nonsteroidal anti-inflammatory drugs (NSAIDs). However, the positive pharmacological effect of NSAIDs is accompanied by a number of side effects. Most NSAIDs non-selectively inhibit the enzyme cyclooxygenase (COX), i.e., they inhibit both COX-2 and COX-1, which in turn leads to frequent damage to the liver, gastrointestinal tract (GI tract), adverse effects on the cardiovascular system. There are also risks of combining NSAIDs with other medicines. Therefore, it is important to develop and study anti-inflammatory drugs from herbal raw materials, which will minimize side effects and conduct long-term treatment of chronic diseases [1-3].

Analysis of the literature and previous phytochemical studies have suggested that plants of the genus Mykolaychyky (m.), namely $m$. flat have anti-inflammatory action. M. flat (Eryngium planum L.) of the family of Umbelliferae (Apiaceae) are widespread in Ukraine and have long been used in folk medicine [4-7]. 
The purpose of the work was to research of acute toxicity and antiinflammatory activity of extracts of Eryngium planum L.

Materials and methods. Acute toxicity was studied in white adult mice of both sexes, which were injected with flat extracts. The model of formalin edema of the hind paw of white rats was used to determine the anti-inflammatory activity of flat extracts. Diclofenac natrium and quercetin were used as comparison drugs.

Results and their discussion. The objects of the study were extracts of $\mathrm{m}$. flat MP-0, MP-4 and MP-7 (extractants: purified water, $40 \%$ or $70 \%$ ethanol, respectively), which were obtained at the Department of Pharmaceutical Management, Drug Technology and Pharmacognosy of the Ivano-Frankivsk National Medical University (IFNMU).

The study of anti-inflammatory activity of new herbal substances is one of the key tasks of pharmacy. However, the primary element of preclinical studies is the study of the toxicity of a new pharmacological substance.

Acute toxicity of flat extracts was studied among white adult mice of both sexes according to the method of Stefanov O.V. [8]. The animals were raised in the IFNMU vivarium and standardized according to physiological and biochemical parameters. Animals were kept in accordance with the requirements of sanitary and hygienic norms in plastic cages on a standard diet. The research was conducted in accordance with international and domestic requirements for humane treatment of animals, which are regulated by the European Convention for the Protection of Vertebrate Animals Used for Experimental and Other Scientific Purposes, Law of Ukraine No. 3447-IV "On Protection of Animals from Cruelty", general ethical principles of animal experiments approved by the First National Congress of Ukraine on Bioethics $[9,10]$.

Extracts of $\mathrm{m}$. flat were injected to animals intragastrically using a probe in a dose of $5000 \mathrm{mg} / \mathrm{kg}$.

The animals were divided into four groups of six individuals each. Animals of the first-third groups were injected with extracts of m. flat MP-0, MP-4, MP-7, respectively. The fourth group - intact animals. 
The animals were observed for 14 days. Evaluated the general condition of the animals, namely:

- mortality;

- breathing;

- motor activity;

- color of the skin, tail, ears and mucous membranes;

- salivation;

- indicators of the state of the gastrointestinal tract (nature and color of feces) [11].

On the $3^{\text {rd }}, 7^{\text {th }}$ and $14^{\text {th }}$ days, control weighing of each individual was performed. On the day $15^{\text {th }}$, the animals were decapitated under general anesthesia, the organs of the subjects were weighed, and blood was collected for biochemical studies [8].

For $m$. flat by $\mathrm{LD}_{50}$ extracts, the maximum administered doses were conventionally accepted because they did not cause animal death. The research results are shown in the Table 1.

Table 1. The results of the study of acute toxicity of extracts of $m$. flats.

\begin{tabular}{|c|c|c|c|}
\hline $\begin{array}{c}\text { The name of the } \\
\text { test substance }\end{array}$ & $\begin{array}{c}\text { Dose, } \\
\mathrm{mg} / \mathrm{kg}\end{array}$ & $\begin{array}{c}\text { Mortality, } \\
\text { number of dead animals / total } \\
\text { number of animals in the group }\end{array}$ & $\begin{array}{c}\text { Class of } \\
\text { toxicity }\end{array}$ \\
\hline $\begin{array}{c}\text { Herbal extract of } m \cdot \\
\text { flat } \text { of MP-0 }\end{array}$ & 5000 & $0 / 6$ & V class \\
\hline $\begin{array}{c}\text { Herbal extract of } m . \\
\text { flat } \text { of MP-4 }\end{array}$ & 5000 & $0 / 6$ & V class \\
\hline $\begin{array}{c}\text { Herbal extract of } m \cdot \\
\text { flat } \text { of MP-7 }\end{array}$ & 5000 & $0 / 6$ & \\
\hline
\end{tabular}

The results shown in the Table 1 indicate that the herbal extracts of $m$. flat can be classified as class V toxicity - almost non-toxic. 
Immediately after the injection of the studied extracts and throughout the experiment, the general condition of the animals was normal. Some important vital indicators are listed in the Table 2.

Table 2. Indicators of the living conditions of the studied animals.

\begin{tabular}{|c|c|c|c|c|}
\hline & \multicolumn{4}{|c|}{ Clinical indicators of animals } \\
\hline Indicators & $\begin{array}{c}\text { Herbal extract } \\
\text { of } m \text {. flat of } \\
\text { MP-0 }\end{array}$ & $\begin{array}{c}\text { Herbal extract } \\
\text { of } m \text {. flat of } \\
\text { MP-4 }\end{array}$ & $\begin{array}{c}\text { Herbal extract } \\
\text { of } m \text {. flat of } \\
\text { MP-7 }\end{array}$ & $\begin{array}{l}\text { Intact } \\
\text { animals }\end{array}$ \\
\hline Salivation & Normal & $\begin{array}{l}\text { In the first } 24 \\
\text { hours moisture } \\
\text { of the hair } \\
\text { around the } \\
\text { mouth }\end{array}$ & $\begin{array}{l}\text { In the first } 24 \\
\text { hours moisture } \\
\text { of the hair } \\
\text { around the } \\
\text { mouth }\end{array}$ & Normal \\
\hline Breath & \multicolumn{4}{|c|}{ Calm, not difficult } \\
\hline Motor activity & \multicolumn{4}{|c|}{ Animals are mobile, coordination is preserved } \\
\hline Cramps & \multicolumn{4}{|c|}{ Absent } \\
\hline $\begin{array}{c}\text { Integumentary } \\
\text { tissues }\end{array}$ & \multicolumn{4}{|c|}{ The coat is dry, white, smooth; tail and paws - light pink } \\
\hline
\end{tabular}

During the study, an increase in body weight of animals was recorded, both in the intact and in the study groups (Fig. 1).

As clear from the Fig. 1, experimental animals of all groups gained weight.

Macroscopic examination of the internal organs of experimental animals of all groups revealed no pathological signs.

The color, shape, size and location of the organs were anatomically correct. Heart muscle was the right shape, dark red in section, the lungs were not changed. The surface of the liver, pancreas and kidneys were homogeneous and smooth. The spleen was elastic and full-blooded. Mass indicators of internal organs are presented in the Table 3. 


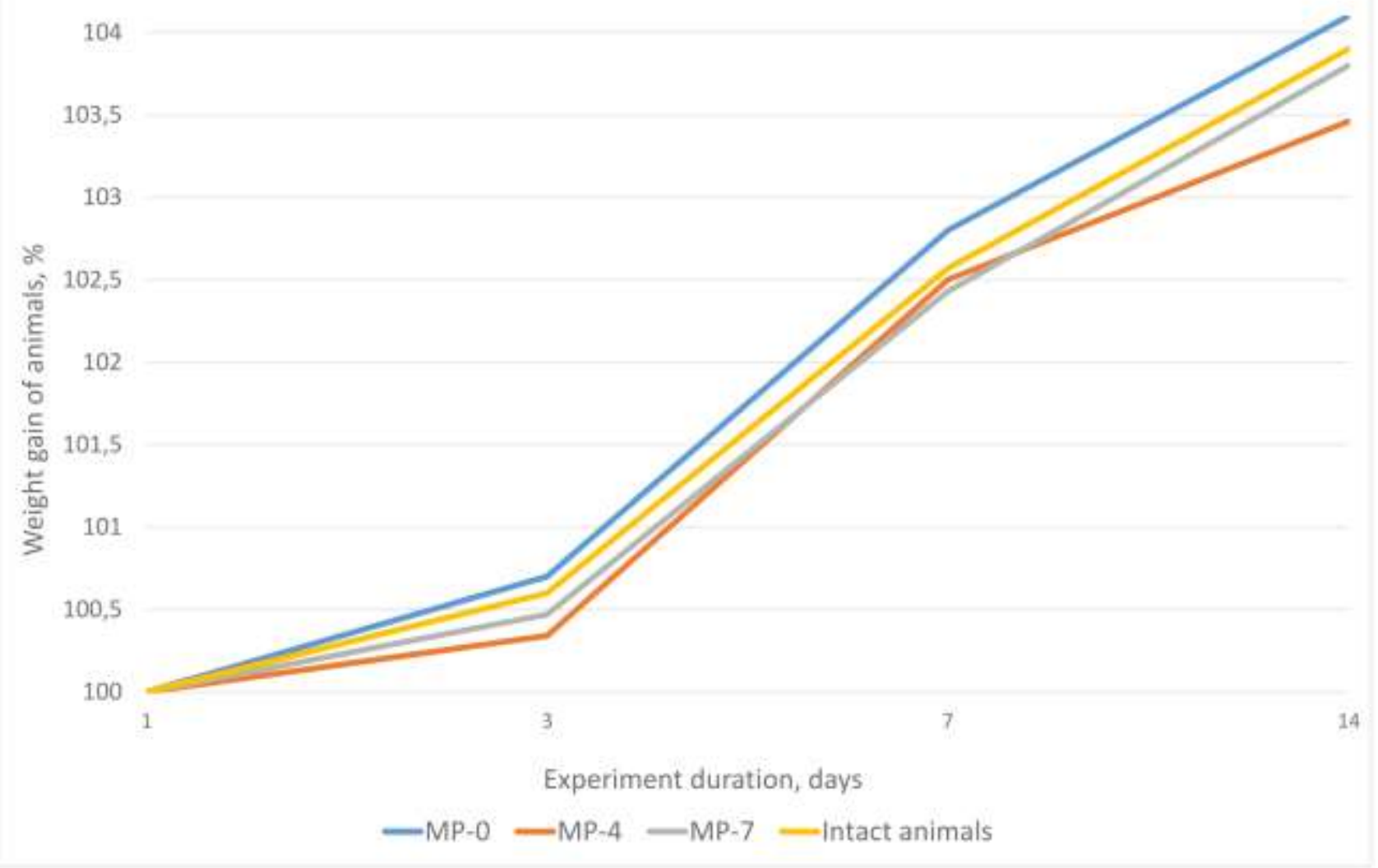

Fig.1. Indicators of weight gain of the studied animals.

The effect of $m$. flat extracts on the biochemical parameters of blood serum on the day $14^{\text {th }}$ was assessed by AST and ALT - Reitman-Frenkel method, using reagent kits from the company "Philisit-Diagnostics" (Ukraine). The indicators are given in the Table 4.

The research results from the Table 4 show that the biochemical parameters of the blood of mice under the influence of herbal extracts of $m$. flat were within normal limits.

Therefore, as a result of the study it was found that intragastric injection of $m$. flat extracts in a dose of $5000 \mathrm{mg} / \mathrm{kg}$ does not violate vital signs of animals and does not lead to their death, which characterizes the extracts as virtually non-toxic (toxicity class $\mathrm{V}, \mathrm{LD}_{50}>5000 \mathrm{mg} / \mathrm{kg}$ ) [8].

The results of the study of the toxicity of herbal extracts of $m$. flat are the basis for the study of their pharmacological activity, including anti-inflammatory. The blood system and connective tissue are primarily involved in the implementation of the inflammatory process. The main components of inflammation, depending on the stage, 
are: alteration, exudation, and proliferation. All mediators of inflammation or their precursors are formed in different cells of the body and are released directly into the site of inflammation [12-13].

Table 3. Mass indicators of internal organs.

\begin{tabular}{|l|l|l|l|l|l|l|}
\hline $\begin{array}{l}\text { Studied } \\
\text { extracts }\end{array}$ & Heart & Lungs & Spleen & Kidneys & Liver \\
\hline Extract of MP-0 & $\begin{array}{l}\text { The mass } \\
\text { of the } \\
\text { organ, g., } \\
\bar{x} \pm \Delta \bar{x}\end{array}$ & $0,108 \pm 0,004$ & $0,22 \pm 0,011$ & $0,15 \pm 0,007$ & $0,30 \pm 0,012$ & $1,32 \pm 0,056$ \\
\hline $\begin{array}{l}\text { Mass } \\
\text { ratio } \\
\text { Extract of MP-4 }\end{array}$ & $\begin{array}{l}\text { The mass } \\
\text { of the } \\
\text { organ, g., } \\
\bar{x} \pm \Delta \bar{x}\end{array}$ & $0,095 \pm 0,005$ & $0,21 \pm 0,008$ & $0,13 \pm 0,006$ & $0,32 \pm 0,016$ & $1,28 \pm 0,057$ \\
\hline $\begin{array}{l}\text { Mass } \\
\text { ratio }\end{array}$ & 0,45 & 1,01 & 0,64 & 1,39 & 6,11 \\
\hline $\begin{array}{l}\text { Extract of MP-7 } \\
\text { The mass } \\
\text { of the } \\
\text { organ, g., } \\
\bar{x} \pm \Delta \bar{x}\end{array}$ & $0,102 \pm 0,005$ & $0,21 \pm 0,009$ & $0,14 \pm 0,006$ & $0,28 \pm 0,007$ & $1,27 \pm 0,031$ \\
\hline $\begin{array}{l}\text { Mass } \\
\text { ratio } \\
\text { The mass } \\
\text { of the } \\
\text { organ, g., } \\
\bar{x} \pm \bar{x}\end{array}$ & $0,094 \pm 0,004$ & $0,20 \pm 0,008$ & $0,12 \pm 0,005$ & $0,29 \pm 0,012$ & $1,23 \pm 0,022$ \\
\hline $\begin{array}{l}\text { Mass } \\
\text { ratio }\end{array}$ & 0,46 & 0,95 & 0,63 & 1,36 & 5,78 \\
\hline
\end{tabular}


Table 4. Biochemical parameters of serum among experimental animals.

\begin{tabular}{|c|c|c|}
\hline Studied agents & AST, $\mu \mathrm{mol} / \mathrm{h} . \mathrm{ml}$ & ALT, $\mu \mathrm{mol} / \mathrm{h} . \mathrm{ml}$ \\
\hline Extract of MP-0 & $0,47 \pm 0,02^{*}$ & $0,29 \pm 0,01^{*}$ \\
\hline Extract of MP-4 & $0,49 \pm 0,02^{*}$ & $0,30 \pm 0,02^{*}$ \\
\hline Extract of MP-7 & $0,48 \pm 0,01^{*}$ & $0,28 \pm 0,01^{*}$ \\
\hline Intact animals & $0,42 \pm 0,02$ & $0,24 \pm 0,01$ \\
\hline
\end{tabular}

Note: $*$ - the significance of the deviation in relation to these groups of intact animals $(\mathrm{p} \leq 0.05)$.

Effects on the tissues of phlogogenic agents are accompanied by changes in the vascular bed, namely arterial and venous hyperemia, increased permeability of vascular walls, which in turn leads to the release of plasma and blood elements into the tissues with the formation of exudate. Edema is one of the main manifestations of the inflammatory process, so a model of aseptic formalin inflammation was used to study the anti-inflammatory activity of $m$. flat extracts [13-14].

Experimental studies were performed on white male rats weighing 180-250 g., which were on a normal diet, divided into six groups of six animals each.

The study and analysis of the obtained experimental data were performed in comparison with the drug from the group of non-steroidal anti-inflammatory drugs natrium diclofenac, which was injected in a dose of $8 \mathrm{mg} / \mathrm{kg}$, and quercetin - in a dose of $5 \mathrm{mg} / \mathrm{kg}$.

A model of aseptic formalin inflammation was used to study the antiinflammatory activity: $0.1 \mathrm{ml}$. of $2 \%$ aqueous formalin solution was injected subplantarly under the aponeurosis of the sole of the hind paw of the rat. For two hours before and immediately after the injection of $2 \%$ formalin solution, animals of the groups 1-3 were orally injected extracts of $m$. flat of MP-0, MP-4 and MP-7 in a dose of $10 \mathrm{mg}$. per $100 \mathrm{~g}$. of body weight, respectively. 
Animals of the group 4 were injected with diclofenac natrium ( $8 \mathrm{mg} / \mathrm{kg})$; Group 5 - quercetin $(5 \mathrm{mg} / \mathrm{kg})$. Animals of the $6^{\text {th }}$ control group were injected with $0.1 \mathrm{ml}$. of $2 \%$ aqueous formalin solution without further treatment.

The volume of the rat's paw was measured oncometrically before the start of the experiment and one, three and five hours after the injection of the phlogogenic agent. The results of the increase in the volume of the paws of rats are given in Tables 5, 6 and on the Fig. 2.

The effect of the studied extracts was evaluated for their ability to inhibit the development of formalin edema in the paws of rats compared with animals in the control group. Indicators of anti-exudative activity are given in the Table 6 .

Suppression of the inflammatory reaction was calculated by the following formula:

$\mathrm{A}=(\mathrm{Vk}-\mathrm{Vd}) / \mathrm{Vk}) * 100$,

where $\mathrm{A}$ is the anti-exudative activity, \%;

$\mathrm{Vk}$ - increase in the volume of the swollen paw in the control group, conv. units;

$\mathrm{Vd}$ - increase in the volume of swollen paw in the study group, conv. from

Table 5. Increase among rats' paw volume.

\begin{tabular}{|l|c|c|c|}
\hline \multirow{2}{*}{\multicolumn{1}{|c|}{ Studied agents }} & \multicolumn{3}{|c|}{ Increase in paw volume of rats, conv. units } \\
\cline { 2 - 4 } & 1 hour & 3 hours & 5 hours \\
\hline Extract of MP-0 & $119,8 \pm 0,66^{*}$ & $129,4 \pm 1,20^{*}$ & $120,6 \pm 0,90^{*}$ \\
\hline Extract of MP-4 & $108,8 \pm 0,34^{*}$ & $118,6 \pm 0,68^{*}$ & $124,5 \pm 0,70^{*}$ \\
\hline Extract of MP-7 & $106,0 \pm 0,27^{*}$ & $108,3 \pm 0,13^{*}$ & $110,5 \pm 0,20^{*}$ \\
\hline Diclofenac natrium & $105,6 \pm 0,89^{*}$ & $105,6 \pm 0,87^{*}$ & $104,2 \pm 0,80^{*}$ \\
\hline Quercetin & $106,8 \pm 1,02^{*}$ & $109,6 \pm 0,88^{*}$ & $112,3 \pm 0,85^{*}$ \\
\hline Control group & $127,5 \pm 0,58$ & $135 \pm 0,63$ & $140 \pm 0,64$ \\
\hline
\end{tabular}

Note: $*$ - the deviation of the indicator is significant relative to the data of the control pathology group $(\mathrm{p}<0,05)$. 
Table 6. Indicator of suppression of inflammatory response among rats.

\begin{tabular}{|l|l|l|l|}
\hline \multirow{2}{*}{ Studied agents } & \multicolumn{3}{|c|}{ Indicator of suppression of the inflammatory reaction, \% } \\
\cline { 2 - 4 } & \multicolumn{2}{|c|}{1 hour } & \multicolumn{2}{c|}{3 hours } & \multicolumn{1}{c|}{5 hours } \\
\hline Extract of MP-0 & 6,01 & 4,17 & 13,83 \\
\hline Extract of MP-4 & 14,65 & 12,13 & 11,06 \\
\hline Extract of MP-7 & 16,85 & 19,80 & 21,05 \\
\hline Diclofenac natrium & 17,21 & 21,81 & 25,60 \\
\hline Quercetin & 16,20 & 18,82 & 19,77 \\
\hline
\end{tabular}

Analysis of the data obtained during the experiment (Tables 5, 6; Fig. 2) shows that $m$. flat extracts showed a sufficiently pronounced anti-inflammatory effect in formalin edema from the first hour of the experiment in comparison with the control group. Herbal extract of $m$. flat of MP-7 on the first, third, and fifth hours of the experiment showed antiexudative activity at $16.85 \%, 19.8 \%$ and $21.05 \%$, respectively, which is close to the reference drug diclofenac sodium $(17,21 \%, 21.81 \%$ and $25.60 \%$ respectively); and exceeded the antiexudative activity of the reference drug quercetin $(16.20 \%, 18.82 \%$ and $19.77 \%$, respectively).

For extracts of MP-4 and MP-7, the maximum growth of rat paws was observed at the fifth hour of the experiment after administration of the phlogogenic agent. Importantly, for the MP-0 extract, the maximum growth of rat paws occurred at the third hour after administration of the phlogogenic agent, and at the fifth hour, unlike other extracts, there was a gradual decrease in rat paw volume.

In the control group of untreated animals, edema increased significantly throughout the experiment. 


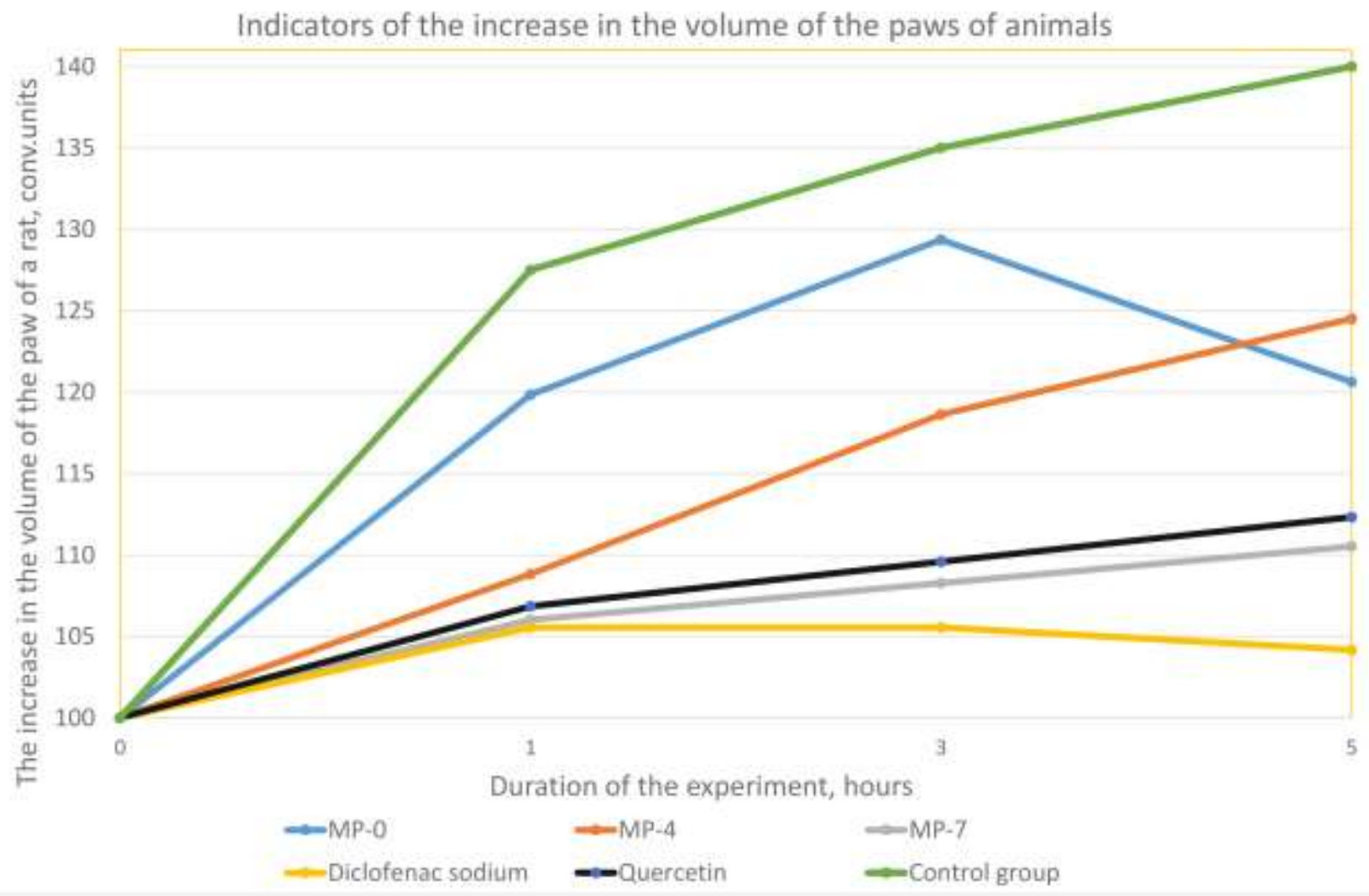

Fig.2. Graphic representation of rats' paws volume gain.

Conclusions. Analysis of the data obtained during the experiment shows that the extracts of $m$. flat belong to the class of low-toxic compounds, and therefore they can be used in the treatment and prevention of pathologies. Extracts of $m$. flat showed a pronounced anti-inflammatory effect in formalin edema from the first hour of the experiment in comparison with the control group. Herbal extract of $m$. flat of MP-7 at the first, third, and fifth hours of the experiment showed antiexudative activity at $16.85 \%, 19.8 \%$ and $21.05 \%$, respectively, which is close to the reference drug diclofenac natrium $(17.21 \%, 21.81 \%$ and $25.60 \%$, respectively), and exceeded the antiexudative activity of the reference drug quercetin $(16.20 \%, 18.82 \%$ and $19.77 \%$, respectively).

For extracts of MP-4 and MP-7, the maximum growth of rat paws was observed at the fifth hour of the experiment after administration of the phlogogenic agent. Importantly, for MP-0 extract, the maximum growth of rat paws occurred at the third hour after administration of the phlogogenic agent; at the fifth hour, in contrast to other extracts, there was a gradual decrease in the volume of the paws of rats. 
In the control group of untreated animals, edema increased significantly throughout the experiment.

Mykolaychyky flat (Eryngium planum L.) are promising species of medicinal plants, as evidenced by the results of study of acute toxicity and anti-inflammatory activity.

Ethical approval. Ethical clearance was obtained from the administration of Ivano-Frankivsk National Medical University. A permission statement for conducting the experiments was received from the administration of Ivano-Frankivsk National Medical University. Before any data collection, the main purpose of the study was clearly explained to each department (concerned personnel).

Conflict of interests. The authors declare that they have no conflict of interests or/and competing interests.

Funding. The authors state, that there was no funding from any agencies for this study.

\section{References.}

1. Zaiko M., Byts Yu., Myslytskyi V. Patofiziolohiia. 4-te vyd. Kyiv: Medytsyna. $2014 ; 752 \mathrm{~s}$.

2. Kalenichenko H., Maloshtan L., Shatalova O. Doslidzhennia mekhanizmu protyzapalnoi dii hustoho ekstraktu z lystia lishchyny zvychainoi. 2015.Ukrainskyi biofarmatsevtychnyi zhurnal.Vol.1.N.6. P.30-33.

3. Hrytsyk R., Kireev I., Struk O., Klymenko A. Doslidzhennia protyzapalnoi aktyvnosti ekstraktiv polynu hirkoho ta polynu zvychainoho za umovy patolohii riznoho henezu. 2020. Medical and Clinical Chemistry. Vol. N. 2. P. 87-93. URL: https://doi.org/10.11603/mcch.2410-681x.2020.v.i2.11365.

4. The Plant List. Royal Botanic Gardens, Kew and Missouri Botanical Garden. 2021. URL: http://www.theplantlist.org/.

5. IPNI. International Plant Names Index. The Royal Botanic Gardens, Kew, Harvard University Herbaria \& Libraries and Australian National Botanic Gardens. 2021. URL: http://www.ipni.org/. 
6. Hrodzinskyi A. Likarski roslyny: entsyklopedychnyi dovidnyk. Kyiv: «Ukrainska entsyklopediia» im. M. P. Bazhana; 1992. 544 s.

7. Grytsyk A., Gnatoyko K. Characteristics of plants of the genus eryngium and prospects of their use in medicine. 2021. SSP Modern Pharmacy and Medicine. Vol.1. N.2. P.1-8. URL: https://doi.org/10.53933/sspmpm.v1i2.27.

8.Stephanov O.V. Doklinichni doslidzhennia likarskykh zasobiv: metodychni rekomendatsii. Preclinical research of drugs: methodical recommendations. 2001. Kyiv: Avitsena. 339 s.

9. European Convention for the Protection of Vertebrate Animals used for Experimental and other Scientific Purposes (ETS No. 123). Strasbourg, 18.III.1986. Council of Europe. URL: https://rm.coe.int/168007a67b.

10. Zakon Ukrainy "Pro zakhyst tvaryn vid zhorstokoho povodzhennia" vid 08.11.2021.

Verkovna

Rada

of

Ukraine.

URL: https://zakon.rada.gov.ua/laws/show/3447-15.

11. Verkhovodova Yu., Kireiev I., Koshovyi O. Vyvchennia hostroi toksychnosti vpershe otrymanykh ekstraktiv shavlii likarskoi. 2019. Art of Medicine. Vol.1. N.2. P.20-24.

12. Puda V.P., Fira L.S., Lykhatskyi P.H. Vyvchennia protyzapalnoi aktyvnosti sukhoho ekstraktu z lystia salatu posivnoho. 2018. Medical and Clinical Chemistry. Vol.1. N.3. P.57-62. URL: https://doi.org/10.11603/mcch.2410-681x.2018.v0.i3.9566. 13. Ataman O. Patofiziolohiia. Vinnytsia. Nova knyha; 2012. $448 \mathrm{~s}$.

14. Shchokina K, Drohovoz S., Maksymov Yu. Porivniannia protyeksudatyvnoi dii suchasnykh nesteroidnykh protyzapalnykh zasobiv. 2004. Liky. N.3-4. P. 34-40. 